\title{
TRANSTORNOS NUTRICIONAIS NA DOENÇA HEPÁTICA CRÔNICA
}

DESCRITORES - Distúrbios nutricionais. Hepatopatias.

No presente número dos ARQUIVOS de GASTROENTEROLOGIA, podemos apreciar lúcida e cuidadosa revisão sobre as interrelações entre desnutrição protéico-energética e doença hepática crônica, da autoria de MAIO et al. ${ }^{(2)}$. O tema não é novo mas mantém sua atualidade e interesse e não somente devido à enorme prevalência de hepatopatias em nosso meio, com muitos milhões de afetados de cirrose, esquistossomose, hepatites crônicas e outras afecções. O reverso da medalha é a noção de que aberrações hepáticas sérias repercutem fatalmente sobre a composição corpórea e o estado nutricional, dado o papel central do órgão no metabolismo de aminoácidos, carboidratos, lípides e muitos outros nutrientes.

Trata-se de consenso quase universal, porém a associação desnutrição-hepatopatia não é linear, nem de fácil interpretação. Dentro de uma mesma entidade, como a hepatopatia alcoólica crônica, reconhece-se há gerações que o bebedor de pinga ou cachaça, muitas vezes desempregado e até sobrevivendo da mendicância, paga tributo substancialmente mais elevado às hipovitaminoses e à atrofia muscular, caminhando mais assiduamente para a caquexia que o consumidor de whisky, embora metabolicamente se trate do mesmo etanol. Evidentemente o alcoólatra de classe média ou alta conta com dieta mais balanceada e orientação médico-nutricional mais regular e confiável porém, se admitirmos que a origem do transtorno está no hepatócito enfermo, estes argumentos perdem parte do seu vigor.

Mesmo advogando-se uma fisiopatologia mista para as carências nutricionais do hepatopata, metabólica mas também dietética, não estaremos a salvo das surpresas e armadilhas. A esquistossomose hepatoesplênica constitui-se num bom exemplo, pois prevalece tipicamente no nordeste do país, acometendo predominantemente as populações desfavorecidas. Uma investigação do estado nutricional de indivíduos parasitados residindo em zona endêmica, deveria, por conseguinte, configurar uma situação clara de má nutrição, uma vez que resultaria da somatória dos efeitos metabólicos e dietéticos da lesão parasitária, ainda que porventura precoce e desprovida de complicações, com as lacunas próprias da alimentação regional.

Em levantamento por nós orientado recentemente a respeito ${ }^{(5)}$, os achados não corresponderam com muita precisão ao modelo teórico previsto. A composição corpórea avaliada antropometricamente, assim como as proteínas plasmáticas, revelaramse inteiramente satisfatórias numa população de trabalhadores assintomáticos com forma intestinal da moléstia. Num segundo grupo de esquistossomose hepatoesplênica compensada, ainda que associada a varizes esofágicas incipientes, as variáveis antropométricas continuaram corretas e somente algumas determinações outras, com ênfase para a taxa de albumina e os testes cutâneos de hiperssensibilidade retardada, denunciaram a existência de desordens alimentares e funcionais moderadas.

Talvez uma das principais fontes de confusão e erros no dimensionamento do problema resida na seleção dos pacientes alvo. Grande parte dos conhecimentos disponíveis 
sobre inter-relações entre hepatopatia alcoólica e nutrição foi coletada em populações hospitalizadas, padecendo de sérios distúrbios como icterícia, ascite, sangramento digestivo, edemas e encefalopatia, e num período em que muitos dos modernos conhecimentos e recursos de terapia nutricional não eram disponíveis. Neste contexto, a avaliação nutricional só poderia consubstanciar desequilíbrios magnos ${ }^{(3)}$. Contingentes ambulatoriais ou assintomáticos com elevada probabilidade, estarão a salvo da maioria dos déficits, porém até mesmo candidatos a transplante hepático, muitos deles em fase terminal da enfermidade, quando assistidos com recursos dietéticos e famacológicos apropriados, demonstram surpreendentemente poucas aberrações nos seus principais compartimentos hídricos, energéticos e protéicos ${ }^{(6)}$.

Um dos pontos mais debatidos no manejo do hepatopata grave diz respeito ao impacto das proteínas dietéticas sobre a ocorrência de coma hepático. Desde a década de 1970, ensaia-se nesta eventualidade a restrição de aminoácidos aromáticos e do reforço da oferta de aminoácidos de cadeia ramificada, porém os benefícios reais de tal política têm sido questionados. Com base em extensa metaanálise elaborada há alguns anos, BLACKBURN e O'KEEFE ${ }^{(1)}$ chegaram à conclusão de que, por via parenteral, os benefícios não podem ser negados, porém são menos persuasivas as evidências no contexto da alimentação enteral. Não é esta a experiência do Hospital das Clínicas de São Paulo, onde a evolução clínica se revela igualmente positiva mediante as duas vias de administração, seja dos aminoácidos ramificados em si, seja de alimentos orais naturais especialmente selecionados para atender aos requisitos de composição de aminoácidos desejada e cujo valor aquisitivo é mais compatível com o padrão econômico das populações desfavorecidas.

Independentemente da opção nutricional selecionada, a limitação à livre prescrição de proteínas face a lesões mais sérias da glândula hepática, tem sido listada como um fator agravante dos desequilíbrios da sua composição corporal. Novamente há razões para discordar desta assertiva, pelo menos na grande maioria das oportunidades. Cirróticos e portadores de hepatite alcoólica sem encefalopatia respondem satisfatoriamente a dietas orais ou enterais à base de caseína, mesmo sem aminoácidos ramificados adicionais, melhorando apreciavelmente a condição nutricional, e até mesmo a função hepatocelular $^{(4)}$.

Em síntese, estão corretos os autores do $\operatorname{artigo}^{(2)}$ quando julgam múltiplas as potenciais razões para desequilíbrio de macronutrientes nas hepatopatias. Além das aqui comentadas, assinalam-se o hipermetabolismo, a deficiência imunológica com processos infecciosos supervenientes, e outros vários. Ao contrário do que se concluía até um passado relativamente recente, o que não é lícito é encarar este panorama certamente complexo com derrotismo ou imobilidade. A doença hepática crônica impõe barreiras, mas os recursos terapêuticos atuais já se mostram à altura dos desafios.

Joel FAINTUCH*

Faintuch J. Nutritional disorders in chronic hepatic disease. Arq Gastroenterol 2000; 37(1):1-2.

HEADINGS - Nutrition disorders. Liver diseases.

\section{REFERÊNCIAS BIBLIOGRÁFICAS}

1. Blackburn GL, O'Keefe SJD. Nutrition in liver failure. Gastroenterology 1989;97:1049-51.

2. Maio R, Dichi JB, Burini RC. Conseqüências nutricionais das alterações metabólicas dos macronutrientes na doença hepática crônica. Arq Gastroenterol 2000;37:52-7.

3. Mendenhall CL, Anderson S, Wesner RE, Goldberg SJ, Crolic KA. Protein-calorie malnutrition associated with alcoholic hepatitis. Am J Med 1984;76:211-22.
4. Nompleggi DJ, Bonkovski HL. Nutritional supplementation in chronic liver disease: an analytical review. Hepatology 1994;19:518-33.

5. Sampietro SMS, Faintuch J, Pinotti HW. Nutritional deficits in asymptomatic Manson's schistosomiais. [Abstract]. Digestion 1998;59(Suppl. 3):645.

6. Vasconcelos MIL, Sette Jr H, Ferraz Neto BH. Composição corpórea em pacientes de transplante de fígado. [Resumo]. Rev Bras Nutr Clin 1997;12(Suppl.2):83.

* Professor Associado da Disciplina de Cirurgia do Aparelho Digestivo da Faculdade de Medicina da Universidade de São Paulo. 